Meinanda Putri Zalsabella ${ }^{1}$ Darmadi $^{2}$

Pupung Puspita Ningrum ${ }^{3}$ Sindi Ardila Yuliarisma ${ }^{4}$ Ayu Safitri ${ }^{5}$

Yohannes Eko Prasetyo ${ }^{6}$

Risvya Faiz Nabila ${ }^{7}$

\section{DAMPAK PEMBELAJARAN JARAK JAUH TERHADAP PERASAAN TERTEKAN PADA SISWA KELAS TUJUH SMP SAAT MEMAHAMI KONSEP MATEMATIKA}

\begin{abstract}
Abstrak
Penelitian ini bertujuan untuk mengetahui dampak dari pembelajaran jarak jauh terhadap perasaan tertekan siswa kelas tujuh SMP saat memahami konsep matematika. Metode yang digunakan dalam penelitian ini adalah metode deskriptif kualitatif. Subjek pada penelitian ini adalah salah satu siswa kelas 7 MTsN Kuncen Madiun dan salah satu siswi kelas 7 SMPN 13 Madiun. Penerapan pembelajaran jarak jauh atau pembelajaran tatap muka di era pendidikan normal baru memiliki implikasi psikologis bagi siswa. Dukungan dari orang tua, guru, dan sesama rekan sangat dibutuhkan agar siswa tidak stres. Kelompok SMP memiliki sederet faktor pendorong penyesuaian, mulai dari ada tidaknya pedoman yang jelas, ketersediaan infrastruktur, hingga tingkat beban tugas. Selain itu, secara psikologis, anak-anak SMP masih dalam masa transisi dari pembelajaran dasar ke menengah. Secara psikologis, yang membuat siswa merasa negatif adalah berkurangnya penguasaan materi utamanya mata pelajaran Matematika selama pembelajaran jarak jauh. Siswa, khususnya, paling terpengaruh selama pembelajaran jarak jauh. Mereka memiliki penyesuaian akademik, interaksi sosial yang terbatas, dan kemungkinan perasaan negatif. Aspek psikologis yang muncul seperti itu tidak bisa ditolerir. Ketidakteraturan dan ketiadaan alat ukur untuk pembelajaran jarak jauh seperti kurikulum yang belum diterbitkan dan penyederhanaan kompetensi dasar semakin berdampak negatif bagi peserta didik.
\end{abstract}

Kata Kunci: PJJ (Pembelajaran Jarak Jauh), Perasaan Tertekan, Konsep Matematika

\footnotetext{
${ }^{1}$ Pendidikan Matematika, Fakultas Keguruan dan Ilmu Pendidikan, Universitas PGRI Madiun meinanda.pz@gmail.com

${ }^{2}$ Pendidikan Matematika, Fakultas Keguruan dan Ilmu Pendidikan, Universitas PGRI Madiun darmadi.mathedu@unipma.ac.id

${ }^{3}$ Pendidikan Matematika, Fakultas Keguruan dan Ilmu Pendidikan, Universitas PGRI Madiun pita.pupung24@gmail.com

${ }^{4}$ Pendidikan Matematika, Fakultas Keguruan dan Ilmu Pendidikan, Universitas PGRI Madiun cindy12say@gmail.com

${ }^{5}$ Pendidikan Matematika, Fakultas Keguruan dan Ilmu Pendidikan, Universitas PGRI Madiun asafitri495@gmail.com

${ }^{6}$ Pendidikan Matematika, Fakultas Keguruan dan Ilmu Pendidikan, Universitas PGRI Madiun y.eko.p200601@gmail.com

${ }^{7}$ Pendidikan Matematika, Fakultas Keguruan dan Ilmu Pendidikan, Universitas PGRI Madiun risvya28@gmail.com
} 


\begin{abstract}
The study was intended to know the impact of long-distance learning on the depressed feelings of seventh graders when understanding math. The method used in this study is a qualitative descriptive method. The subject of this study is one of the 7th graders MTSN Kuncen Madiun and one of the 7th graders SMPN 13 Madiun. The application of long distance in a new normal age of education has psychological implications for students. Support from parents, teachers, and fellow partners is urgently needed to prevent students from stress. Junior high school groups have a range of adaptive factors, ranging from a lack of clear guidelines, infrastructure availability, to a degree of duty. Furthermore, psychologically, junior high student are still in transition from primary to secondary learning. Psychologically, what makes students feel negative is the lack of major material mastery in course of mathematics during long distance study. Students, in particular, are affected most during long range learning. They had academic adjustments, limited social interaction, and possible negative feelings. The psychological aspect of appearing like that is intolerable. Regularity and lack of instruments for long-distance learning such as the unpublished curriculum and the simplification of basic competence are increasingly negative for learners.
\end{abstract}

Keywords: Long Distance Learning, Oppressed, Mathematical Concept.

\title{
PENDAHULUAN
}

Sejak pertengahan bulan Maret tahun 2020, pemerintah mulai memberikan himbauan untuk belajar dirumah untuk mengurangi resiko penyebaran virus Corona. Himbauan tersebut berisi, semua peserta didik beserta guru harus mmberlakukan program belajar di rumah atau menggunakan Pembelajaran Jarak Jauh. Pembelajaran Jarak Jauh (PJJ) sendiri berlangsung dengan guru dapat menyampaikan materi ajar kepada peserta didik tanpa harus bertatap muka langsung di dalam suatu ruangan yang sama.

(Prawiyogi, Purwanugraha, Fakhry, \& Firmansyah, 2020) Pembelajaran Jarak Jauh (PJJ) adalah pembelajaran dengan menggunakan suatu media sehingga terjadi interaksi antara pendidik dan peserta didik tanpa bertatap muka secara langsung. Pada pelaksanaannya ada beberapa faktor penting yang harus diperhatikan, agar sistem pembelajaran jarak jauh bisa berjalan dengan baik, yaitu perhatian, kreatif menggunakan alat serta menjalin interaksi yang baik dengan peserta didik, dan dapat mengoperasikan gadget serta memanfaatkan aplikasi yang ada sebagai media pembelajaran.

Pembelajaran jarak jauh ini memiliki beberapa kendala yang belum bisa ditangani saat ini, yaitu tidak semua orang tua bisa membimbing pembelajaran di rumah karena urusan pekerjaan. Sehingga tak jarang beberapa peserta didik merasa tertekan dengan pembelajaran dan tugastugas yang diberikan, khususnya matematika. Peserta didik merasa sulit untuk memahami pembelajaran yang diberikan karena tidak ada yang membimbing mereka secara langsung. Tentu hal ini perlu diperhatikan, karena perasaan tertekan dapat menimbulkan stress dan kecemasan dalam diri peserta didik. Berikut kendala pelaksanaan Pembelajaran Jarak Jauh, antara lain:

1) Listrik padam saat mengakses program pembelajaran online.

2) Jaringan internet yang buruk.

3) Komitmen yang tidak menentu dari orang tua dan siswa.

4) Anak-anak yang lambat belajar.

5) Anak yang tidak konsisten dengan jadwal belajarnya.

Beberapa permasalahan tersebut seperti yang diungkapkan oleh Rusman, dkk (2013:271) yaitu:

"akses untuk mengikuti pembelajaran sering terjadi masalah bagi pembelajar". 
(Sukadiyanto, 2010) Suatu tekanan atau sesuatu yang terasa menekan dalam diri individu merupakan stress. Sesuatu tersebut dapat terjadi disebabkan oleh ketidakseimbangan antara harapan dan kenyataan yang dinginkan oleh individu, baik keinginan yang bersifat jasmaniah maupun rohaniah. Misalnya, peserta didik merasa bahwa materi tentang aljabar mudah seperti yang dijelaskan dalam pembelajaran namun tugas yang diberikan ternyata lebih sulit.

Mata pelajaran matematika dianggap oleh sebagian siswa sebagai mata pelajaran yang sulit dan biasanya pembelajaran matematika membutuhkan konsentrasi yang tinggi. Saat ini masih banyak siswa yang kesulitan belajar matematika. Mereka menganggap matematika sebagai mata pelajaran yang menakutkan, membosankan, dan membebani siswa karena abstrak, penuh angka dan rumus sehingga menimbulkan kecemasan pada siswa saat melaksanakan pembelajaran matematika. (Anditya \& Murtiyasa, 2016) Sedangkan kecemasan khususnya kecemasan matematika merupakan perasaan tertekan maupun rasa gugup yang mengganggu dalam memanipulasi angka dan melakukan pemecahan permasalahan matematika yang luas, baik di dalam kehidupan sehari-hari maupun di dalam proses pembelajaran (Ranjan dan Gunendra Chandra, 2013). Menurut George Brown College (2014), kecemasan matematika merupakan perasaan tertekan yang mempengaruhi kemampuan matematika, sikap negatif terhadap matematika ataupun merasa kurang percaya diri terhadap matematika. Peneliti menyimpulkan bahwa kecemasan matematika merupakan perasaan tertekan, khawatir, cemas, gelisah, tidak suka, maupun rasa takut seseorang terhadap segala sesuatu yang berkaitan dengan matematika. Kecemasan matematika berdampak buruk terhadap pelaksanaan dan hasil dari pembelajaran matematika.

\section{METODE}

Metode yang digunakan dalam penelitian ini adalah metode deskriptif kualitatif. Bentuk penelitian yang digunakan adalah penelitian survey dan wawancara, yang bertujuan untuk melihat hubungan Dampak PJJ terhadap perasaan tertekan pada siswa saat memahami konsep matematika. Subjek dalam penelitian ini adalah siswa kelas VII tahun ajaran 2020/2021, dengan objek penelitian berupa tingkat perasaan tertekan siswa, kemampuan siswa dalam menyelesaikan masalah matematika, serta hubungan kecemasan dan kemampuan siswa dalam menyelesaikan masalah matematika. Teknik pengumpulan data yang digunakan dalam penelitian ini adalah komunikasi secara langsung dengan alat pengumpul data (instrumen penelitian) berupa pertanyaan dan nilai matematika yang didapatkan saat mengerjakan tugas serta ujian di sekolah untuk mengukur kemampuan siswa dalam menyelesaikan masalah matematika dan perasaan tertekan siswa.

Peneliti menjadi instrumen kunci karena peneliti merupakan satu-satunya pengumpul data dan memerankan diri sebagai pengamat dengan tujuan mengetahui kondisi dan mendapatkan informasi secara langsung kepada subjek. Pertanyaan tersebut berupa pertanyaan yang disampaikan langsung kepada subjek untuk dijawab. Sumber datanya adalah Siswa kelas 7 SMP/MTs. Sumber data dalam penelitian ini yaitu hasil dari pertanyaan dan dokumentasi. Sumber data dicatat melalui catatan tertulis, sedangkan dokumen dapat berupa video selama berlangsungnya wawancara.

\section{HASIL DAN PEMBAHASAN}

Berikut adalah hasil pengamatan pada subjek pertama yaitu salah satu siswa kelas 7 MTsN Kuncen Madiun dan subjek kedua yaitu salah satu siswi kelas 7 SMPN 13 Madiun. 
Tabel 1. Hasil Wawancara Subjek

\begin{tabular}{|c|c|c|c|}
\hline No. & Pertanyaan & Subjek 1 & Subjek 2 \\
\hline 1. & Menyukai pelajaran matematika & Iya & Lumayan \\
\hline 2. & Sistem pembelajaran jarak jauh efektif & Lumayan & Lumayan \\
\hline 3. & $\begin{array}{lrrr}\text { Mengalami } & \text { kesulitan } & \text { dengan } & \text { sistem } \\
\text { pembelajaran jarak jauh } & & \\
\end{array}$ & Lumayan & Iya \\
\hline 4. & $\begin{array}{l}\text { Dalam pelajaran matematika materi yang } \\
\text { disampaikan dapat dipahami dengan mudah } \\
\text { selama pembelajaran jarak jauh }\end{array}$ & Lumayan & Iya \\
\hline 5. & $\begin{array}{l}\text { Mudah dalam mengerjakan tugas pelajaran } \\
\text { matematika selama pembelajaran jarak jauh }\end{array}$ & $\begin{array}{l}\text { Iya, kadang- } \\
\text { kadang juga } \\
\text { mengalami } \\
\text { kesulitan }\end{array}$ & $\begin{array}{l}\text { Iya, kadang- } \\
\text { kadang juga } \\
\text { mengalami } \\
\text { kesulitan }\end{array}$ \\
\hline 6. & $\begin{array}{l}\text { Nilai yang didapatkan dalam mengerjakan } \\
\text { tugas dan ujian pelajaran matematika }\end{array}$ & $\begin{array}{ll}\text { Baik, } & \text { diatas } \\
\text { rata-rata } & \end{array}$ & $\begin{array}{lr}\text { Baik, } & \text { diatas } \\
\text { rata-rata } & \end{array}$ \\
\hline 7. & $\begin{array}{l}\text { Saat mengerjakan tugas dan ujian pelajaran } \\
\text { matematika merasakan tertekan }\end{array}$ & Kadang-kadang & Kadang-kadang \\
\hline 8. & $\begin{array}{l}\text { Orang tua mendampingi dan membantu } \\
\text { menjelaskan tentang materi yang kurang } \\
\text { dipahami }\end{array}$ & $\begin{array}{l}\text { Tidak, tetapi ada } \\
\text { kakak yang mau } \\
\text { membantu } \\
\text { menjelaskan } \\
\text { saat waktu } \\
\text { senggang }\end{array}$ & $\begin{array}{l}\text { Tidak, tetapi ada } \\
\text { kakak yang mau } \\
\text { membantu } \\
\text { menjelaskan } \\
\text { saat waktu } \\
\text { senggang }\end{array}$ \\
\hline
\end{tabular}

Berdasarkan hasil wawancara dengan kedua subjek menunjukkan bahwa sistem pembelajaran jarak jauh kurang efektif. Menurut subjek 1, sistem pembelajaran jarak jauh masih kurang efektif dikarenakan sebagian atau beberapa guru hanya memberikan materi tanpa menjelaskan dan setiap ada yang bertanya guru kurang merespon dengan cepat. Sedangkan menurut subjek 2, sistem pembelajaran jarak jauh memiliki positif dan negatifnya tetapi lebih ke negatif karena setiap pembelajaran berlangsung terkendala sinyal sehingga susah untuk memahami pembelajaran. Kedua subjek dapat mengerjakan tugas dan memahami materi pelajaran matematika meskipun terkendala beberapa hal, dikarenakan mereka menyukai pelajaran matematika sehingga masih mampu untuk mempelajarinya secara mandiri dan dengan bantuan dari kakak mereka. Namun mereka masih merasa tertekan saat mengerjakan ujian (ulangan harian) dilaman lms karena terkadang sinyal terkendala sehingga gagal untuk menginput jawaban. Karena hal tersebut mereka kurang fokus dalam mengerjakan ujian karena takut jika jawaban tidak terinput dan waktu segera habis.

\section{SIMPULAN}

Pembelajaran jarak jauh (PJJ) kurang efektif, dikarenakan beberapa atau sebagian guru hanya memberikan materi tanpa menjelaskan dan setiap ada yang bertanya guru tidak merespon dengan cepat serta setiap pembelajaran berlangsung terkendala oleh sinyal sehingga sulit untuk memahami pembelajaran. Sehingga benar adanya beberapa kendala dalam pembelajaran jarak jauh yaitu:

1. Listrik padam saat mengakses program pembelajaran online.

2. Jaringan internet yang buruk. 
3. Komitmen yang tidak menentu dari orang tua dan siswa.

4. Anak-anak yang lambat belajar.

5. Anak yang tidak konsisten dengan jadwal belajarnya.

Pada dasarnya setiap siswa dapat memahami materi secara mandiri, akan tetapi karena kendalakendala tadi mereka merasa cemas dan tertekan. Mereka tidak dapat mengerjakan tugas dan soal-soal dengan fokus, karena fokus mereka teralihkan pada kondisi jaringan internet. Mereka takut jika tugas tidak bisa disubmit tepat waktu, dan pengerjaan mereka menjadi sia-sia.

Sebaiknya guru memberikan penjelasan terhadap materi yang diberikan berupa video yang dapat ditonton kapan saja, sehingga siswa tidak perlu takut jika ada kendala jaringan. Tenggang waktu untuk pengerjaan tugas sebaiknya lama dan guru harus memiliki opsi pengiriman tugas selain melalui lms jika terdapat kendala jadi siswa tidak perlu khawatir. Jika ulangan harian dan ujian tenggang waktu yang diberikan tetap sama, akan tetapi guru harus memiliki opsi pengumpulan pengerjaan ulangan melalui aplikasi lain yang lebih mudah.

\section{DAFTAR PUSTAKA}

Anditya, R., \& Murtiyasa, B. (2016). Faktor-Faktor Penyebab Kecemasan Matematika. Universitas Muhammadiyah Surakarta, 1-18.

Mediana. (2020, Juli 13). Siswa Alami Dampak Psikologis Pembelajaran Jarak Jauh Paling Nyata. Dipetik September 17, 2020, dari Kompas: https://bebas.kompas.id/baca/bebasakses/2020/07/13/siswa-alami-dampak-psikologis-pembelajaran-jarak-jauh-palingnyata/

Prawiyogi, A. G., Purwanugraha, A., Fakhry, G., \& Firmansyah, M. (2020). Efektifitas Pembelajaran Jarak Jauh Terhadap Pembelajaran Sisiwa di SDIT Cendekia Purwakarta. Jurnal Pendidikan Dasar, 94-101.

Sakarti, H., Mirza, A., \& Hamdani. (2016). Hubungan Kecemasan dan Kemampuan Siswa dalam Menyelesaikan Masalah Matematika. Fakultas Keguruan dan Ilmu Pendidikan Universitas Tanjungpura, 1-12.

Sukadiyanto. (2010). Stress dan Cara Menguranginya. Cakrawala Pendidikan, 55-66.

Supriyo. (2015, Januari 14). Kecemasan Maematika. Dipetik September 17, 2020, dari Orang Purworejo: http://orangporjo.blogspot.com/2015/01/model-konseling-cognitivebehavior.html 